\title{
SOLOS E VEGETAÇÃO DOS PICOS CAMACUÃ, CAMAPUÃ \\ E TUCUM - CAMPINA GRANDE DO SUL - PR ${ }^{1}$
}

\author{
SOIL AND VEGETATION OF THE CAMACUÃ, CAMAPUÃ \\ AND TUCUM PEAKS -CAMPINA GRANDE DO SUL - PR
}

\author{
Yury VASHCHENKO 2 \\ Ricardo Prado PIOVESAN ${ }^{3}$ \\ Marcelo Ricardo de LIMA 4 \\ Nerilde FAVARETTO 5
}

\begin{abstract}
RESUMO
O objetivo deste trabalho foi caracterizar, classificar e correlacionar os solos e a vegetação que ocorrem nos picos Camacuã, Camapuã e Tucum. A vegetação original foi classificada e caracterizada fisionomicamente. Perfis de solo foram abertos, descritos e amostrados para análise química e granulométrica. Ocorrem três formações fitofisionomias distintas na área, sendo duas arbóreas (Floresta Ombrófila Mista e Floresta Ombrófila Densa) e uma herbácea (Refúgio Vegetacional). A fisionomia da Floresta Ombrófila Densa sofre alteração com o aumento da altitude, havendo redução da altura e do diâmetro das árvores e do número de estratos arbóreos. Foram identificadas cinco classes de solos (incluindo Neossolos Litólicos e Cambissolos). Estes solos são, em geral, rasos, com baixa fertilidade, ácidos e com alto teor de carbono orgânico. Observase relação entre os solos e a vegetação, sendo que quanto maior o teor de argila e a disponibilidade de nutrientes no solo, maior o porte e mais complexa a vegetação sobre este.
\end{abstract}

Palavras-chave: região altomontana; levantamento; pedologia.

\begin{abstract}
The objective of this work was to characterize, to classify and to observe the relationship between the soil and the vegetation that occur on the Camacuã, Camapuã and Tucum peaks. The original vegetation was classified and the vegetation physiognomy was characterized. Soil profiles were exposed for morphologic description, sampling for chemical and particle size analysis. It was identified three distinct phytogeographical formations, being two arboreal ("Floresta Ombrófila Mista" and "Floresta Ombrófila Densa") and one herbaceous ("Refúgio Vegetacional"). The physiognomy a of the "Floresta Ombrófila Densa" was altered by the altitude. The height, the diameter of the trees and the tree forest strata number had diminished with the increase of the altitude. Five soil classes were identified (Entisols and Inceptisols), which present small depth, low fertility, high acidity and organic carbon content. There is relation between soil and vegetation, and as the clay content and the soil nutrient availably increase, the high of the tree also increase, been complex the vegetation.
\end{abstract}

Key-words: high altitude region; survey; pedology.

\footnotetext{
1 Parte da Dissertação de Mestrado do primeiro autor, apresentada à Universidade Federal do Paraná

${ }^{2}$ Engenheiro Florestal, Mestre em Ciência do Solo. E-mail: vashchenko_01@yahoo.com.br

${ }^{3}$ Engenheiro Agrônomo, Mestre em Ciência do Solo. E-mail: rppiovesan@yahoo.com.br

${ }^{4}$ Engenheiro Agrônomo, Doutor em Agronomia, Professor do Departamento de Solos e Engenharia Agrícola da UFPR, Rua dos Funcionários, 1540, 80035-050, Curitiba - PR, E-mail: mrlima@ufpr.br.

${ }^{5}$ Engenheira Agrônoma, Ph.D., Professora do Departamento de Solos e Engenharia Agrícola da UFPR, Rua dos Funcionários, 1540, 80035-050, Curitiba - PR, E-mail: nfavaretto@ufpr.br.
} 


\section{INTRODUÇÃO}

A Serra do Mar constitui um sistema montanhoso que se estende desde o Espírito Santo até o sul de Santa Catarina. No Estado do Paraná constitui a zona limítrofe entre o litoral e o primeiro planalto, formando serras marginais descontínuas, que se elevam de 500 a $900 \mathrm{~m}$ acima do nível do planalto, sendo mais escarpada do lado do Atlântico que do continental e dotada de taludes íngremes e vertentes vigorosas (BIGARELLA, 1978).

No Paraná, a Serra do Mar é formada por vários blocos de montanhas, sendo o maior deles conhecido como Ibitiraquire. Neste bloco se encontram os picos Camacuã, Camapuã e Tucum que possuem $1.550 \mathrm{~m}, 1.706 \mathrm{~m}$ e $1.736 \mathrm{~m}$ de altitude, respectivamente. Estes picos apresentam um relevo suave, configurando cumes arredondados, os quais são cobertos por uma extensa área de vegetação herbácea, mesclada com afloramentos de rochas, que abrange continuamente os três picos, constituindo assim uma paisagem muito diferente da encontrada nos outros picos da região, que apresentam um relevo escarpado, constituindo cumes íngremes e com pequenas e esporádicas áreas de campo, as quais em poucos casos apresentam algum afloramento de rocha.

Os solos e a vegetação dos ambientes altomontanos no Paraná são pouco estudados, principalmente devido à declividade e à vegetação densa que dificultam o acesso a esses ambientes. Com o intuito de ampliar as informações sobre os solos e a vegetação em áreas altomontanas na Serra do Mar paranaense, especificamente na Serra Ibitiraquire, escolheu-se os picos Camacuã, Camapuã e Tucum como área de estudo, devido à sua peculiaridade paisagística.

Assim, os objetivos do presente trabalho foram caracterizar, classificar e correlacionar os solos e a vegetação que ocorrem nos picos Camacuã, Camapuã e Tucum.

\section{MATERIAL E MÉTODOS}

A área de estudo localiza-se no estado do Paraná, especificamente na Serra lbitiraquire na parte da Serra do Mar que compõe a Área Especial de Interesse Turístico (AEIT) do Marumbi. A Serra Ibitiraquire (Serra Verde em Tupi) está localizada nos municípios de Antonina e Campina Grande do Sul. Na parte que compreende o município de Campina Grande do Sul, na localidade denominada Terra Boa, estão localizados os picos Camacuã, Camapuã e Tucum (Figura 1), (entre as coordenadas 712.000 $\mathrm{m}$ e $718.000 \mathrm{~m}$ W e $7.203 .500 \mathrm{~m}$ e $7.206 .500 \mathrm{~m} \mathrm{~S}$ no sistema UTM, Fuso 22 sul, Meridiano Central 51ํㅡㄴ 00'00"), parcialmente inseridos na área do Parque Estadual do Pico Paraná. O acesso a estes picos é feito pela rodovia BR 116, saindo de Curitiba e percorrendo aproximadamente $50 \mathrm{~km}$ até a localidade Terra Boa, onde se percorre cerca de 5 $\mathrm{km}$ em uma estrada de terra ao local denominado chácara do Milani, onde a trilha de acesso aos picos tem início.

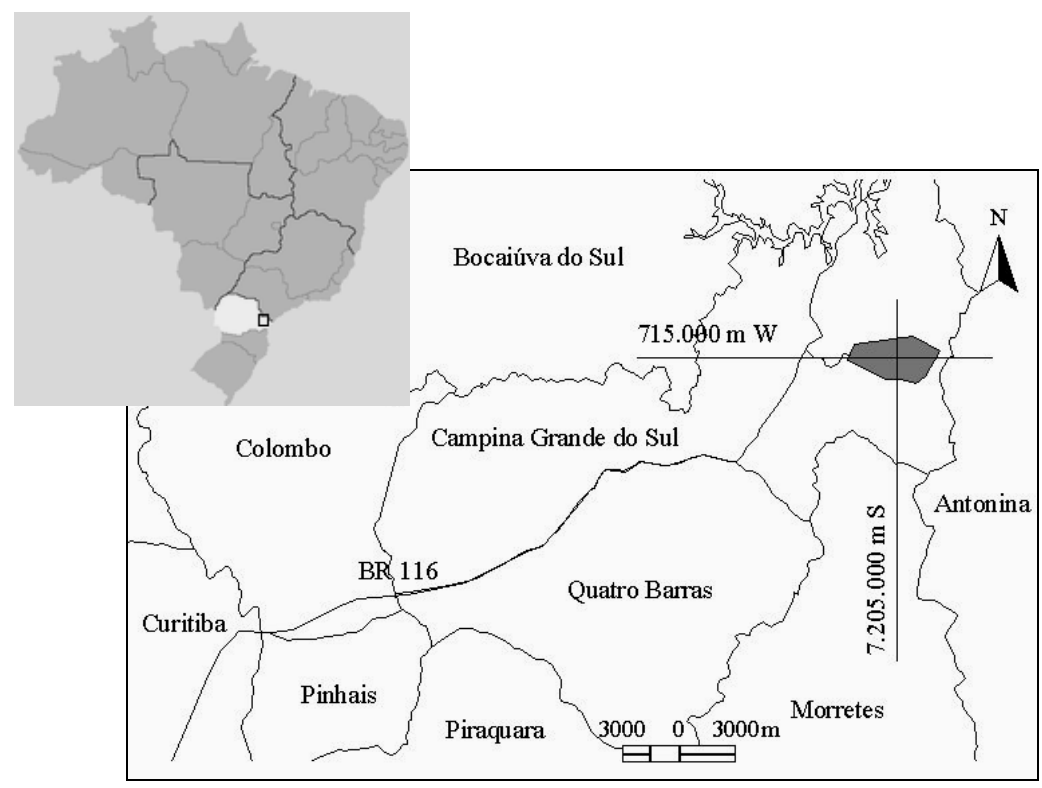

FIGURA 1 - Localização dos picos Camacuã, Camapuã e Tucum, Campina Grande do Sul, PR. 
Segundo a classificação de Köppen, o clima da região é temperado - Cfb - caracterizado por temperatura média no mês mais frio abaixo de $18{ }^{\circ} \mathrm{C}$ (mesotérmico), com verões frescos, temperatura média no mês mais quente abaixo de $22^{\circ} \mathrm{C}$ e sem estação seca definida (IAPAR, 1994). A área encontra-se sobre um bloco granítico, denominado Granito Graciosa, rocha intrusiva originada há mais de 600 milhões de anos no período Pré-Cambriano. São observados sistemas de fendas, diáclases e falhamentos (CORDANI e GIRARDI, 1967). O relevo é predominantemente montanhoso (45 a $75 \%$ de declividade), com altitudes variando de 880 a $1736 \mathrm{~m}$ e presença de vales profundos em forma de $\mathrm{V}$ (VASHCHENKO et al., 2007).

O mapeamento da vegetação original foi realizado a partir do mapa digital da vegetação, com escala 1:50.000 (SEMA, 2002) e do reconhecimento em campo através da observação das características fisionômicas da vegetação. A vegetação original foi classificada de acordo com IBGE (1992), a qual foi caracterizada fisionomicamente conforme SEMA (1998), em relação ao diâmetro das árvores, à existência de epífitas ou lianas, à altura das árvores do dossel e ao número de estratos arbóreos, todos foram estimados visualmente.

Para a caracterização dos solos primeiramente foram efetuadas tradagens e coleta de amostras dos solos para verificar a similaridade e delimitá-los preliminarmente. As tradagens foram efetuadas ao longo da trilha de acesso com um trado holandês, observando os diversos padrões de relevo, drenagem e vegetação. Neste procedimento, verificou-se que houve relação entre a vegetação e a ocorrência dos solos. Paralelamente às tradagens, foram coletadas 10 amostras por horizonte (A, B e C) de cada classe preliminar de solo. Essas 10 amostras originaram uma amostra composta para cada horizonte (A, B e C) de cada classe preliminar de solo, as quais foram utilizadas para a realização de análise química, granulométrica e dispersão de argila em água.

As amostras de solo foram secadas em estufa a $65 \stackrel{\circ}{\circ}$ por $48 \mathrm{~h}$ e peneiradas em peneira com malha de $2 \mathrm{~mm}$. As análises químicas $\left(\mathrm{Ca}^{2+}\right.$, $\mathrm{Mg}^{2+}, \mathrm{Na}^{+}, \mathrm{K}^{+}$e $\mathrm{Al}^{3+}$ trocáveis, acidez potencial $(\mathrm{H}+$ $\mathrm{Al}$ ), $\mathrm{P}$ disponível extraído por Mehlich-1, carbono orgânico, $\mathrm{pH}$ em $\mathrm{CaCl}_{2}$ e índice SMP), foram realizadas no Laboratório de Fertilidade do Solo do Departamento de Solos e Engenharia Agrícola da Universidade Federal do Paraná (DSEA/UFPR), conforme as metodologias descritas em MARQUES e MOTTA (2003).

A análise granulométrica (areia, silte e argila total) e a argila dispersa em água, determinadas pelo método do densímetro, foram realizadas no Laboratório de Física do Solo do DSEA/UFPR, conforme as metodologias descritas em EMBRAPA (1997). Antes de realizar a análise granulométrica houve a oxidação da matéria orgânica com $\mathrm{H}_{2} \mathrm{O}_{2}$ nas amostras com teor de carbono acima de $50 \mathrm{~g} \mathrm{~kg}^{-1}$.

A partir dos resultados das análises químicas e físicas calcularam-se os valores de grau de floculação, soma de bases (SB), capacidade de troca de cátions (valor T), atividade de argila, saturação de bases (V), saturação de alumínio (Sat. $\mathrm{Al}$ ), e saturação de sódio (Sat. $\mathrm{Na}$ ) de acordo com EMBRAPA (1997).

Após a análise dos dados químicos e físicos confirmou-se a diferença entre os solos observada em campo na delimitação preliminar e determinou-se a escolha dos locais para abertura de perfis para a descrição geral e morfológica dos horizontes de acordo com SANTOS et al. (2005), permitindo a classificação definitiva dos solos de acordo com EMBRAPA (2006).

\section{RESULTADOS E DISCUSSÃO}

A área de estudo é coberta por duas florestas distintas, a Floresta Ombrófila Densa, também conhecida como Floresta Atlântica e a Floresta Ombrófila Mista, também conhecida como Floresta com Araucária. Na Figura 2 está apresentada a cobertura original de cada formação, sendo que ocorre apenas a formação Montana na Floresta Ombrófila Mista e as formações Montana e Altomontana na Floresta Ombrófila Densa. Além das Florestas Ombrófila Densa e Mista, a área apresenta o Refúgio Vegetacional, o qual está localizado nos topos.

Serão descritos os tipos vegetacionais, os solos ocorrentes e a correlação entre ambos, iniciando no Refúgio Vegetacional (cotas mais altas) e seguindo no sentido da toposeqüência até a Floresta Ombrófila Mista (cotas mais baixas).

\section{Área de Refúgio Vegetacional}

Acima dos $1.040 \mathrm{~m}$ de altitude cobrindo as partes convexas do terço superior das encostas voltadas para o norte e nos topos dos picos Camacuã (1.550 m), Camapuã (1.706 m) e Tucum (1.736 m), observa-se o Refúgio Vegetacional (Figura 2), cuja fisionomia é caracterizada por plantas herbáceas, com até $50 \mathrm{~cm}$ de altura, entre estas plantas são encontrados bromélias e arbustos isolados, tendo uma fisionomia totalmente diferente da encontrada nas florestas. Estas características são semelhantes às observadas por BENITES et al. (2003a), que descrevem ainda a existência de touceiras formadas por plantas herbáceas de aspecto graminóide e de esparsas ervas não graminóides, as quais formam mosaicos com os afloramentos rochosos.

Nas áreas de ocorrência do Refúgio Vegetacional (Figura 2) o solo predominante (Tabelas 1 a 4 - perfil 1) foi classificado como Neossolo Litólico Hístico típico com afloramento de rocha. A sua posição no relevo favorece os processos erosivos naturais e não permite 0 espessamento do solo, constituindo-se apenas por um horizonte $O$ hístico, camada superficial de material orgânico com teor de carbono igual a 150 $\mathrm{g} \mathrm{kg}^{-1}$, com $14 \mathrm{~cm}$ de espessura sobre contato lítico (Tabela 1). Segundo ROSSI e QUEIROZ NETO (2001) a declividade acentuada, o material de origem e os altos índices pluviométricos limitam o espessamento do solo. 


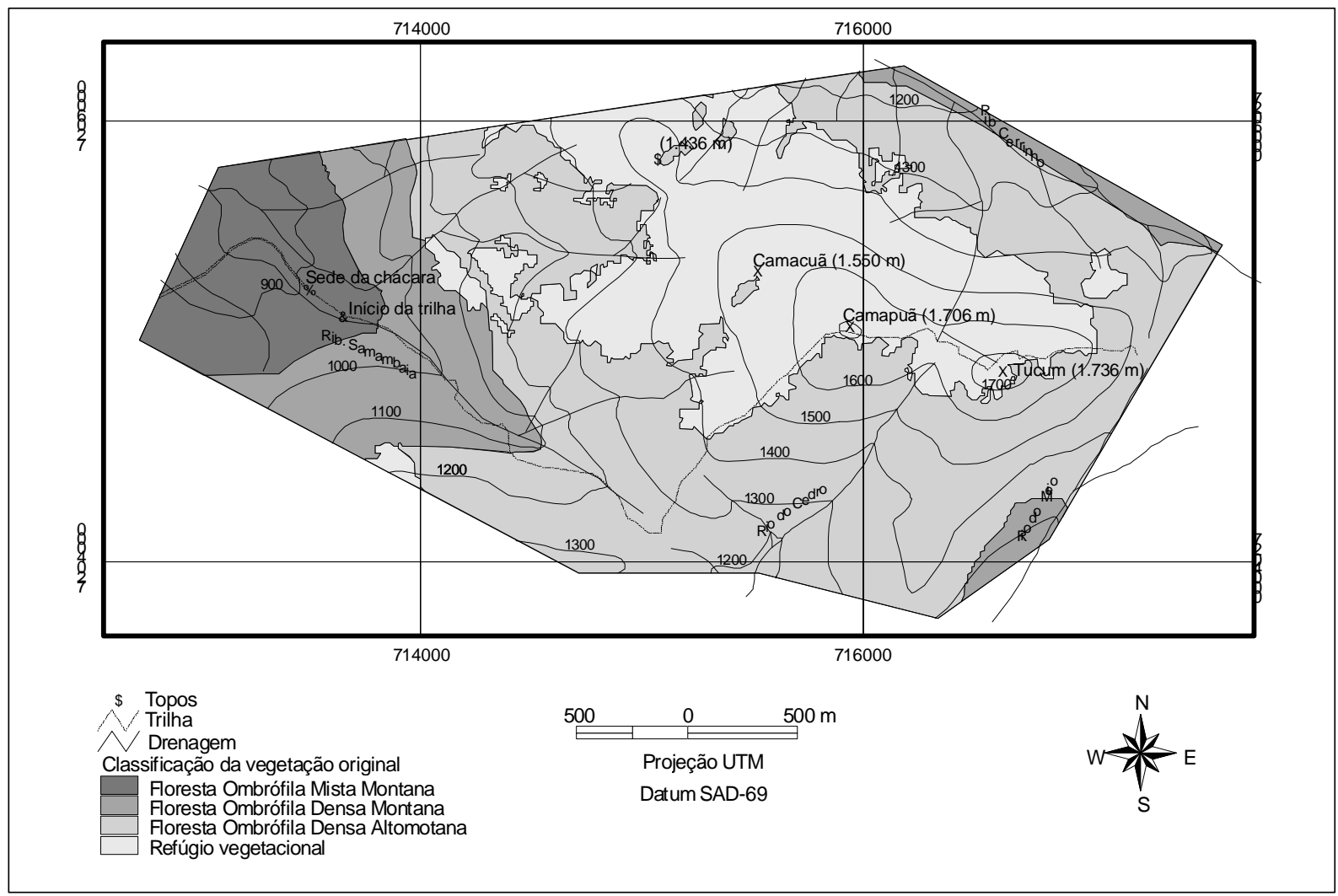

FIGURA 2 - Mapa da vegetação original dos picos Camacuã, Camapuã e Tucum - Campina Grande do Sul, PR, 2006.

TABELA 1 - Teores de areia, argila, silte, argila dispersa em água, fósforo $(P)$, carbono $(C)$ orgânico e pH em $\mathrm{CaCl}_{2}$ e índice SMP em cada horizonte dos solos dos picos Camacuã, Camapuã e Tucum, Campina Grande do Sul, PR, 2006.

\begin{tabular}{|c|c|c|c|c|c|c|c|c|c|c|c|}
\hline \multirow[t]{2}{*}{ Horizonte } & \multirow[t]{2}{*}{$\begin{array}{l}\text { Prof. } \\
(\mathrm{cm})\end{array}$} & \multicolumn{4}{|c|}{$\begin{array}{c}\text { Composição Granulométrica da Terra } \\
\text { Fina }\left(\mathrm{g} \mathrm{kg}^{-1}\right)\end{array}$} & \multirow{2}{*}{$\begin{array}{c}\text { Argila } \\
\text { dispersa } \\
\text { em água } \\
\left(\mathrm{g} \mathrm{kg}^{-1}\right)\end{array}$} & \multirow{2}{*}{$\begin{array}{c}\text { Grau de } \\
\text { floculação } \\
\left(\mathrm{g} \mathrm{kg}^{-1}\right)\end{array}$} & \multirow[t]{2}{*}{$\begin{array}{l}\mathrm{pH} \mathrm{em} \\
\mathrm{CaCl}_{2}\end{array}$} & \multirow[t]{2}{*}{$\begin{array}{l}\text { Índice } \\
\text { SMP }\end{array}$} & \multirow[t]{2}{*}{$\begin{array}{c}\mathrm{P} \\
\left(\mathrm{mg} \mathrm{kg}^{-1}\right)\end{array}$} & \multirow{2}{*}{$\begin{array}{c}\mathrm{C} \\
\text { orgânico } \\
\left(\mathrm{g} \mathrm{kg}^{-1}\right)\end{array}$} \\
\hline & & $\begin{array}{c}\text { Areia } \\
\text { grossa }\end{array}$ & $\begin{array}{c}\text { Areia } \\
\text { fina }\end{array}$ & Silte & Argila & & & & & & \\
\hline \multicolumn{12}{|c|}{ Perfil 01 - Neossolo Litólico Hístico típico } \\
\hline Od & $0-14$ & 530 & 50 & 380 & 30 & 0 & 1000 & 3,6 & 4,3 & 9,2 & 149,74 \\
\hline \multicolumn{12}{|c|}{ Perfil 02 - Neossolo Litólico Distrófico típico } \\
\hline Oo & $10-0$ & - & - & - & - & - & - & - & - & - & - \\
\hline A & $0-10$ & 510 & 30 & 210 & 250 & 0 & 1000 & 3,4 & 4,0 & 5,0 & 70,94 \\
\hline \multicolumn{12}{|c|}{ Perfil 03 - Neossolo Litólico Húmico típico } \\
\hline Oo & $5-0$ & - & - & - & - & - & - & - & - & - & - \\
\hline A & $0-23$ & 490 & 40 & 240 & 230 & 0 & 1000 & 4,1 & 4,5 & 5,3 & 56,66 \\
\hline \multicolumn{12}{|c|}{ Perfil 04 - Cambissolo Húmico Distrófico léptico } \\
\hline Oo & $10-0$ & - & - & - & - & - & - & - & - & - & - \\
\hline A & $0-17$ & 450 & 90 & 270 & 180 & 182 & 818 & 4,0 & 4,9 & 8,4 & 75,00 \\
\hline $\mathrm{Bi}$ & $17-34$ & 390 & 80 & 260 & 270 & 250 & 750 & 4,0 & 4,8 & 5,1 & 40,36 \\
\hline $\mathrm{C}$ & $34-55$ & 520 & 70 & 210 & 200 & 83 & 917 & 4,2 & 5,0 & 5,3 & 26,63 \\
\hline \multicolumn{12}{|c|}{ Perfil 05 - Neossolo Litólico Distrófico típico } \\
\hline Oo & $2-0$ & - & - & - & - & - & - & - & - & - & - \\
\hline A & $0-20$ & 520 & 100 & 130 & 250 & 0 & 1000 & 3,6 & 4,7 & 5,0 & 37,34 \\
\hline \multicolumn{12}{|c|}{ Perfil 06 - Cambissolo Háplico Ta Distrófico lítico } \\
\hline A & $0-10$ & 420 & 80 & 170 & 330 & 0 & 1000 & 3,9 & 5,2 & 4,2 & 27,53 \\
\hline $\mathrm{Bi}$ & $10-20$ & 410 & 90 & 150 & 350 & 333 & 667 & 3,9 & 5,3 & 3,9 & 21,60 \\
\hline $\mathrm{C}$ & $20-40$ & 400 & 100 & 170 & 330 & 400 & 600 & 4,0 & 5,2 & 4,6 & 12,12 \\
\hline
\end{tabular}

Nota: Os perfis foram apresentados na ordem decrescente da altitude e conforme aparecem no relevo, sendo que o perfil 01 encontra-se no topo do morro e o perfil 06 na base. 
VASHCHENKO, Y. et al. Solos e vegetação dos picos...

TABELA 2 - Teores de cálcio $\left(\mathrm{Ca}^{2+}\right)$, magnésio $\left(\mathrm{Mg}^{2+}\right)$, sódio $\left(\mathrm{Na}^{+}\right)$, potássio $\left(\mathrm{K}^{+}\right)$, e alumínio $\left(\mathrm{Al}^{3+}\right)$ trocáveis, acidez potencial $(\mathrm{H}+\mathrm{Al})$, soma de bases $(\mathrm{SB})$, Capacidade de troca de cátions (Valor $\mathrm{T})$, atividade de argila, saturação por bases (V), saturação de alumínio (Sat. Al), e saturação de sódio (Sat. Na) nos solos dos picos Camacuã, Camapuã e Tucum, Campina Grande do Sul, PR, 2006.

\begin{tabular}{|c|c|c|c|c|c|c|c|c|c|c|c|c|}
\hline \multirow[t]{2}{*}{ Horizonte } & $\mathrm{Ca}^{2+}$ & $\mathrm{Mg}^{2+}$ & $\mathrm{Na}^{+}$ & $\mathrm{K}^{+}$ & $\mathrm{Al}^{3+}$ & $\mathrm{H}+\mathrm{Al}$ & SB & Valor T & \multirow{2}{*}{$\begin{array}{c}\text { Atividade de } \\
\text { argila }\left(\mathrm{cmol}_{\mathrm{c}} \mathrm{kg}^{-1}\right. \\
\text { de argila) }\end{array}$} & $\mathrm{V}$ & Sat. Al & Sat. $\mathrm{Na}$ \\
\hline & \multicolumn{8}{|c|}{ - } & & \multicolumn{3}{|c|}{---------- $(\%)$---------- } \\
\hline \multicolumn{13}{|c|}{ Perfil 01 - Neossolo Litólico Hístico típico } \\
\hline Od & 0,8 & 0,6 & 0,14 & 0,34 & 6,7 & 36,1 & 1,93 & 38,07 & 1269,08 & 5,06 & 77,78 & 0,38 \\
\hline \multicolumn{13}{|c|}{ Perfil 02 - Neossolo Litólico Distrófico típico } \\
\hline Oo & - & - & - & - & - & - & - & - & - & - & - & - \\
\hline$A$ & 0,4 & 0,4 & 0,09 & 0,13 & 9,9 & 31,4 & 1,07 & 32,51 & 130,06 & 3,3 & 90,20 & 0,26 \\
\hline \multicolumn{13}{|c|}{ Perfil 03 - Neossolo Litólico Húmico típico } \\
\hline Oo & - & - & - & - & - & - & - & - & - & - & - & - \\
\hline A & 1,4 & 1,1 & 0,04 & 0,26 & 3,7 & 20,6 & 2,74 & 23,34 & 101,48 & 11,73 & 57,20 & 0,17 \\
\hline \multicolumn{13}{|c|}{ Perfil 04 - Cambissolo Húmico Distrófico léptico } \\
\hline Oo & - & - & - & - & - & - & - & - & - & - & - & - \\
\hline A & 7,2 & 2,2 & 0,06 & 0,63 & 2,4 & 16,7 & 10,1 & 26,82 & 148,97 & 37,81 & 18,89 & 0,22 \\
\hline $\mathrm{Bi}$ & 2,5 & 1,6 & 0,05 & 0,33 & 2,0 & 13,9 & 4,53 & 18,46 & 68,38 & 24,52 & 30,20 & 0,25 \\
\hline $\mathrm{C}$ & 1,1 & 0,9 & 0,04 & 0,25 & 1,6 & 11,4 & 2,25 & 13,66 & 68,29 & 16,47 & 42,02 & 0,32 \\
\hline \multicolumn{13}{|c|}{ Perfil 05 - Neossolo Litólico Distrófico típico } \\
\hline Oo & - & - & - & - & - & - & - & - & - & - & - & - \\
\hline A & 3,5 & 1,7 & 0,05 & 0,42 & 1,5 & 14,8 & 5,71 & 20,50 & 82,00 & 27,86 & 20,44 & 0,22 \\
\hline \multicolumn{13}{|c|}{ Perfil 06 - Cambissolo Háplico Ta Distrófico lítico } \\
\hline A & 1,0 & 0,6 & 0,06 & 0,14 & 2,0 & 10,3 & 1,8 & 12,13 & 36,75 & 14,85 & 51,99 & 0,47 \\
\hline $\mathrm{Bi}$ & 1,0 & 0,8 & 0,04 & 0,13 & 1,9 & 9,4 & 1,98 & 11,41 & 32,60 & 17,32 & 49,13 & 0,39 \\
\hline C & 1,2 & 0,7 & 0,04 & 0,11 & 1,8 & 9,9 & 2,03 & 11,96 & 36,24 & 16,97 & 46,51 & 0,37 \\
\hline
\end{tabular}

Nota: Os perfis foram apresentados na ordem decrescente da altitude e conforme aparecem no relevo, sendo que o perfil 01 encontra-se no topo do morro e o perfil 06 na base.

TABELA 3 - Aspectos morfológicos (cor úmida, textura, estrutura e consistência) dos horizontes dos solos dos picos Camacuã, Camapuã e Tucum, Campina Grande do Sul, PR, 2006.

\begin{tabular}{|c|c|c|c|c|}
\hline Horizonte & Cor úmida & Textura & Estrutura & Consistência \\
\hline \multicolumn{5}{|c|}{ Perfil 01 - Neossolo Litólico Hístico típico } \\
\hline Od & 10YR $3 / 2$ & FA & $2, \mathrm{P}$ e Bs & $\mathrm{Fi}, \mathrm{NP}$ e $\mathrm{LPe}$ \\
\hline \multicolumn{5}{|c|}{ Perfil 02 - Neossolo Litólico Distrófico típico } \\
\hline Oo & - & - & - & - \\
\hline A & $7,5 Y R 2,5 / 2$ & FAA & $1, \mathrm{M}$ e Bs & $\mathrm{Fr}, \mathrm{P}$ e LPe \\
\hline \multicolumn{5}{|c|}{ Perfil 03 - Neossolo Litólico Húmico típico } \\
\hline Oo & - & - & - & - \\
\hline A & 10YR $3 / 3$ & FAA & 2, $\mathrm{P}$ e Bs & $\mathrm{Fi}, \mathrm{NP}$ e LPe \\
\hline \multicolumn{5}{|c|}{ Perfil 04 - Cambissolo Húmico Distrófico léptico } \\
\hline Oo & - & - & - & - \\
\hline A & 10YR $3 / 3$ & FA & $1, \mathrm{P}$ e $\mathrm{Gr}$ & $\mathrm{S}, \mathrm{NP}$ e LPe \\
\hline $\mathrm{Bi}$ & 10YR 3/4 & FAA & 1, $\mathrm{P}$ e Gr & $\mathrm{S}, \mathrm{NP}$ e LPe \\
\hline $\mathrm{C}$ & 10YR 3/6 & FAA & $1, \mathrm{G}$ e Bs & Fr, NP e LPe \\
\hline \multicolumn{5}{|c|}{ Perfil 05 - Neossolo Litólico Distrófico típico } \\
\hline Oo & - & - & - & - \\
\hline A & 10YR 3/4 & FAA & $2, \mathrm{P}$ e Bs & $\mathrm{Fi}, \mathrm{NP}$ e $\mathrm{LPe}$ \\
\hline \multicolumn{5}{|c|}{ Perfil 06 - Cambissolo Háplico Ta Distrófico lítico } \\
\hline A & 10YR 3/6 & FAA & 1, M e Gr & $\mathrm{S}, \mathrm{NP}$ e LPe \\
\hline $\mathrm{Bi}$ & 10YR $5 / 6$ & FAA & $1, \mathrm{G}$ e Bs & $\mathrm{S}, \mathrm{NP}$ e LPe \\
\hline C & 10YR 4/6 & FAA & $1, \mathrm{G}$ e Co & $\mathrm{S}, \mathrm{NP}$ e LPe \\
\hline
\end{tabular}

Textura: FA-franco-arenosa, FAA-franco-argilo-arenosa.

Estrutura: 1-fraca, 2-moderada; P-pequena, M-média, G-grande; Gr-granular, BS- blocos sub-angulares, Co-colunar. Consistência: S-solta, Fr-friável, Fi-firme; NP-não-plástica, P-plástica; LPe-ligeiramente pegajosa.

Nota: Os perfis foram apresentados na ordem decrescente da altitude e conforme aparecem no relevo, sendo que o perfil 01 encontra-se no topo do morro e o perfil 06 na base. 
TABELA 4 - Descrição geral dos perfis dos solos (classificação do solo, altitude, relevo local, situação, pedregosidade, rochosidade, erosão, drenagem, vegetação original e atual) dos picos Camacuã, Camapuã e Tucum, Campina Grande do Sul, PR, 2006.

\begin{tabular}{|c|c|c|c|c|c|c|c|}
\hline $\begin{array}{l}\text { Altitude } \\
(\mathrm{m})\end{array}$ & $\begin{array}{c}\text { Relevo local } \\
\text { (Declividade - \%) }\end{array}$ & Situação & $\begin{array}{c}\text { Pedregosidade e } \\
\text { Rochosidade }\end{array}$ & Erosão & Drenagem & Vegetação original & $\begin{array}{l}\text { Vegetação } \\
\text { atual }\end{array}$ \\
\hline \multicolumn{8}{|c|}{ Perfil 01 - Neossolo Litólico Hístico típico } \\
\hline 1.700 & $\begin{array}{l}\text { Suave ondulado } \\
\qquad(08)\end{array}$ & Topo de morro & $\begin{array}{c}\text { Não pedregosa e } \\
\text { Rochosa }\end{array}$ & $\begin{array}{l}\text { Não } \\
\text { visível }\end{array}$ & $\begin{array}{c}\text { Bem } \\
\text { drenado }\end{array}$ & $\begin{array}{c}\text { Refúgio } \\
\text { Vegetacional }\end{array}$ & $\begin{array}{l}\text { Vegetação } \\
\text { nativa }\end{array}$ \\
\hline \multicolumn{8}{|c|}{ Perfil 02 - Neossolo Litólico Distrófico típico } \\
\hline 1.370 & $\begin{array}{l}\text { Forte ondulado } \\
\text { (45) }\end{array}$ & $\begin{array}{l}\text { Terço superior } \\
\text { da encosta }\end{array}$ & $\begin{array}{c}\text { Não pedregosa e } \\
\text { Não rochosa }\end{array}$ & $\begin{array}{l}\text { Não } \\
\text { visível }\end{array}$ & $\begin{array}{c}\text { Bem } \\
\text { drenado }\end{array}$ & $\begin{array}{l}\text { Floresta Ombrófila } \\
\text { Densa Altomontana }\end{array}$ & $\begin{array}{l}\text { Vegetação } \\
\text { secundária }\end{array}$ \\
\hline \multicolumn{8}{|c|}{ Perfil 03 - Neossolo Litólico Húmico típico } \\
\hline 1.230 & $\begin{array}{c}\text { Plano } \\
(01)\end{array}$ & $\begin{array}{c}\text { Terço médio da } \\
\text { encosta e fundo } \\
\text { de vale }\end{array}$ & $\begin{array}{c}\text { Não pedregosa e } \\
\text { Não rochosa }\end{array}$ & $\begin{array}{l}\text { Não } \\
\text { visível }\end{array}$ & $\begin{array}{c}\text { Bem } \\
\text { drenado }\end{array}$ & $\begin{array}{l}\text { Floresta Ombrófila } \\
\text { Densa Altomontana }\end{array}$ & $\begin{array}{l}\text { Vegetação } \\
\text { secundária }\end{array}$ \\
\hline \multicolumn{8}{|c|}{ Perfil 04 - Cambissolo Húmico Distrófico léptico } \\
\hline 1.110 & $\begin{array}{l}\text { Suave ondulado } \\
\text { (09) }\end{array}$ & $\begin{array}{c}\text { Terço inferior da } \\
\text { encosta e fundo } \\
\text { de vale }\end{array}$ & $\begin{array}{c}\text { Não pedregosa e } \\
\text { Não rochosa }\end{array}$ & $\begin{array}{l}\text { Não } \\
\text { visível }\end{array}$ & $\begin{array}{c}\text { Bem } \\
\text { drenado }\end{array}$ & $\begin{array}{l}\text { Floresta Ombrófila } \\
\text { Densa Montana }\end{array}$ & $\begin{array}{l}\text { Vegetação } \\
\text { secundária }\end{array}$ \\
\hline \multicolumn{8}{|c|}{ Perfil 05 - Neossolo Litólico Distrófico típico } \\
\hline 1.050 & $\begin{array}{l}\text { Suave ondulado } \\
\qquad(08)\end{array}$ & $\begin{array}{c}\text { Terço inferior da } \\
\text { encosta e fundo } \\
\text { de vale }\end{array}$ & $\begin{array}{c}\text { Não pedregosa e } \\
\text { Não rochosa }\end{array}$ & $\begin{array}{l}\text { Não } \\
\text { visível }\end{array}$ & $\begin{array}{c}\text { Bem } \\
\text { drenado }\end{array}$ & $\begin{array}{l}\text { Floresta Ombrófila } \\
\text { Densa Montana }\end{array}$ & $\begin{array}{l}\text { Vegetação } \\
\text { nativa }\end{array}$ \\
\hline \multicolumn{8}{|c|}{ Perfil 06 - Cambissolo Háplico Ta Distrófico lítico } \\
\hline 930 & $\begin{array}{l}\text { Ondulado } \\
\text { (19) }\end{array}$ & $\begin{array}{l}\text { Base de morro e } \\
\text { fundo de vale }\end{array}$ & $\begin{array}{c}\text { Não pedregosa e } \\
\text { Moderadamente } \\
\text { rochosa }\end{array}$ & $\begin{array}{l}\text { Não } \\
\text { visível }\end{array}$ & $\begin{array}{c}\text { Bem } \\
\text { drenado }\end{array}$ & $\begin{array}{l}\text { Floresta Ombrófila } \\
\text { Mista Montana }\end{array}$ & $\begin{array}{l}\text { Vegetação } \\
\text { secundária }\end{array}$ \\
\hline
\end{tabular}

Nota: Os perfis foram apresentados na ordem decrescente da altitude e conforme aparecem no relevo, sendo que o perfil 01 encontra-se no topo do morro e o perfil 06 na base.

O Neossolo Litólico Hístico típico (perfil 1) apresenta o menor teor de argila e maior teor de carbono, com baixa saturação por bases (distrófico) e caráter alítico (Tabelas 1 e 2), provavelmente devido aos altos índices pluviométricos, pois a água transporta os compostos mais solúveis (BENITES et al., 2005). Estas características contribuem para que a vegetação arbórea não se desenvolva como nos outros ambientes encontrados na área estudada.

O elevado teor de carbono orgânico (> $50 \mathrm{~g}$ $\mathrm{kg}^{-1}$ ) (EMBRAPA, 1997) encontrado no Neossolo Litólico Hístico típico (Tabela 1 - perfil 1) indica baixa decomposição da matéria orgânica, verificada pela cor escura do solo (bruno-acinzentado-escuro) como citaram BENITES et al. (2005), SIMAS et al. (2005) e BENITES et al. (2003b). A baixa decomposição da matéria orgânica se deve à baixa atividade microbiana, ocasionada pelas baixas temperaturas na região associadas à baixa disponibilidade de nutrientes no solo, sendo que os elevados teores de alumínio trocável também podem contribuir limitar a atividade microbiana (VOLKOFF et al., 1984; BENITES et al. 2001; DIAS et al., 2003a).

O material orgânico também pode apresentar melanização (cor escura) em função da quantidade de fragmentos de carvão encontrados no solo, pois nas áreas de refúgio é comum a ocorrência de queimadas, as quais favorecem a permanência da vegetação herbácea que apresenta adaptações às condições adversas do solo e ao fogo (BENITES et al., 2003a). Os fragmentos de carvão são fontes de carbono para a gênese de substâncias húmicas. Os ácidos húmicos produzidos são muito reativos e aumentam significantemente o valor da atividade de argila, pois este tipo de solo apresenta fração mineral composta principalmente de areia e argila de baixa atividade (BENITES et al., 2005 e BENITES et al., 2003b).

\section{Área de Floresta Ombrófila Densa Altomontana}

A Floresta Ombrófila Densa Altomontana (Figura 2) ocorre entre 1.060 e $1.700 \mathrm{~m}$ de altitude, sendo observada nas partes convexas e côncavas, na face sul, das encostas e nos vales dos rios. A fisionomia desta formação caracteriza-se por árvores tortuosas cobertas por epífitas, sendo aproximadamente $90 \%$ briófitas. A altura das árvores varia de 15 a $5 \mathrm{~m}$ de altura, diminuindo conforme 0 aumento da altitude. Ocorre apenas um estrato arbóreo, o dossel, com diâmetros que variam entre 10 e $40 \mathrm{~cm}$ aproximadamente. Estas características também são descritas por PORTES e GALVÃO (2002).

$\mathrm{Na}$ área de Floresta Ombrófila Densa Altomontana os solos predominantes (Tabelas 1 a 4 - perfis 2 e 3 ) foram classificados como Neossolo Litólico Distrófico típico, representado pelo perfil 2 (que apresenta horizonte $\mathrm{O}$, constituído apenas por folhas não decompostas, com $10 \mathrm{~cm}$ de espessura e horizonte A mineral, também, com $10 \mathrm{~cm}$ de espessura, assentado diretamente sobre a rocha) e Neossolo Litólico Húmico típico, representado pelo perfil 3 (que apresenta o horizonte A com $23 \mathrm{~cm}$ de espessura e horizonte $\mathrm{O}$, constituído por folhas não decompostas, sendo a espessura deste igual a 5 $\mathrm{cm}$ ). A ocorrência de Neossolo Litólico Húmico sob a Floresta Ombrófila Densa Altomontana também 
foi observada por RODERJAN (1994) no morro Anhangava, situado próximo à área de estudo.

O Neossolo Litólico Distrófico típico é encontrado nos vales e nas partes côncavas e convexas (face sul) dos terços médio e superior das encostas (Tabela 4 - perfil 2). Esta posição no relevo favorece o acúmulo de argila e a formação de um horizonte mineral. Segundo ROSSI et al. (2005), quanto maior o teor de argila maior a retenção de água, conseqüentemente mais úmido o solo. Entretanto a declividade acentuada ocasiona uma maior perda de bases pela lixiviação e maior acúmulo de alumínio. Já o Neossolo Litólico Húmico típico, que é encontrado no fundo dos vales às margens dos rios nos terços médio e superior da encosta (Tabela 4 - perfil 3), possui maior espessura e saturação por bases e menor teor de carbono e saturação por alumínio em relação ao Neossolo Litólico Distrófico típico (Tabelas 1 e 2), justificando o maior porte da vegetação sobre o Neossolo Litólico Húmico típico e uma maior decomposição da matéria orgânica, que é indicada por uma coloração mais clara (bruno-escuro) e menor teor de carbono orgânico. Portanto verifica-se que, nesta situação de vales estreitos, as altas declividades das encostas favorecem a perda de sedimentos, os quais se acumulam nos fundos dos vales formando solos mais profundos cobertos por vegetação de maior porte, como observado por ROCHA (1999).

Em relação ao Neossolo Litólico Hístico típico (perfil 1), o Neossolos Litólicos Distrófico típico (perfil 2) e Neossolo Litólico Húmico típico (perfil 3) apresentam maior saturação por alumínio e menor saturação por bases, porém apresentam horizonte mineral e maior teor de argila (Tabelas 1 e 2), o que provavelmente favorece a ocorrência da Floresta Ombrófila Densa Altomontana sobre estes solos.

\section{Área de Floresta Ombrófila Densa Montana}

A Floresta Ombrófila Densa Montana ocorre entre 930 e $1.420 \mathrm{~m}$ de altitude, nos vales nos terços médio e inferior da encosta (Figura 2). A fisionomia desta formação é caracterizada por árvores eretas cobertas por epífitas, como bromeliáceas, orquidáceas e briófitas, sendo que aproximadamente $90 \%$ destas epífitas são bromélias. As lianas também são marcantes nesta formação, sendo que as lianas herbáceas são raras, enquanto que as lianas lenhosas são abundantes. Outra característica marcante é a presença de palmeiras no sub-bosque da floresta, o que não ocorre na Floresta Ombrófila Densa Altomontana e nem na Floresta Ombrófila Mista. $\mathrm{Na}$ Floresta Ombrófila Densa Montana ocorre o dossel, o sub-bosque e um estrato intermediário, sendo que a altura das árvores do dossel é de aproximadamente $30 \mathrm{~m}$ e com grande amplitude diamétrica, ocorrendo indivíduos com mais de 1,0 $\mathrm{m}$ de diâmetro.

Ao comparar a fisionomia da Floresta Ombrófila Densa Montana com a da Floresta Ombrófila Densa Altomontana, observa-se que ocorre uma alteração fisionômica conforme o aumento da altitude, sendo que a altura e o diâmetro das árvores e o número de estratos arbóreos diminuem. Ocorre também uma alteração no tipo de epífitas que cobrem as árvores predominantemente, passando de bromeliáceas e orquidáceas para briófitas. Segundo PORTES e GALVÃO (2002) esta mudança está relacionada à mudança dos fatores climáticos e geográficos, como diminuição da temperatura e aumento da precipitação e forma das cadeias montanhosas, assim como dos fatores pedológicos.

Nas áreas de Floresta Ombrófila Densa Montana os solos predominantes (Tabelas 1 a 4 perfis 4 e 5) foram classificados como Cambissolo Húmico Distrófico léptico (perfil 4) e Neossolo Litólico Distrófico típico (perfil 5).

O Cambissolo Húmico Distrófico léptico (perfil 4) apresenta horizontes O, A, B e C com 10, 17,17 e $19 \mathrm{~cm}$ de espessura, respectivamente. $O$ horizonte $O$ é constituído apenas por folhas não decompostas, enquanto que os horizontes $A, B$ e $C$ são constituídos predominantemente por matéria mineral, com 75, 40 e $26 \mathrm{~g} \mathrm{~kg}^{-1}$ de carbono orgânico, respectivamente. Apresenta, ainda, atividade de argila igual a $68 \mathrm{cmol}_{\mathrm{c}} \mathrm{kg}^{-1}, 24 \%$ de saturação por bases e contato lítico a $54 \mathrm{~cm}$ da superfície do solo. Já o Neossolo Litólico Distrófico típico (perfil 5) apresenta horizonte A com $20 \mathrm{~cm}$ de espessura, saturação por bases igual a $28 \%$, e $37 \mathrm{~g} \mathrm{~kg}^{-1} \mathrm{de}$ carbono, e horizonte $\mathrm{O}$, constituído por folhas não decompostas com a espessura de $2 \mathrm{~cm}$ (Tabelas 1, 2 e 3).

O Cambissolo Húmico Distrófico léptico (perfil 4) e Neossolo Litólico Distrófico típico (perfil 5) são encontrados no fundo do vale, no terço inferior da encosta (Tabela 4). Nessa porção do relevo o vale apresenta uma largura superior à encontrada nos vales das porções mais elevadas, o que possibilita a existência de extensas áreas com relevo plano às margens do ribeirão Samambaia, nas quais é encontrado o Neossolo Litólico Distrófico típico (perfil 5), enquanto que o Cambissolo Húmico Distrófico léptico (perfil 4) está localizado numa faixa de transição entre as encostas e o fundo do vale. Devido a essa posição o Cambissolo recebe sedimentos e nutrientes erodidos naturalmente dos solos das porções mais elevadas, favorecendo a pedogênese, o que lhe confere a maior espessura.

O Cambissolo Húmico Distrófico léptico (perfil 4) e o Neossolo Litólico Distrófico típico (perfil 5) apresentam teores de argila e de nutrientes semelhantes, porém a menor saturação por alumínio no Neossolo, permite uma maior decomposição da matéria orgânica, evidenciada pela cor bruno-amarelo-escuro e o menor teor de carbono orgânico enquanto que no Cambissolo verifica-se um elevado teor de matéria orgânica no horizonte $A$, indicado pela cor bruno-escuro (Tabelas 1, 2 e 3).

A presença da Floresta Ombrófila Densa Montana sobre estes solos se deve provavelmente à menor saturação por alumínio e maior saturação por bases em relação aos outros solos encontrados na área (Tabela 2).

\section{Área de Floresta Ombrófila Mista}

A Floresta Ombrófila Mista Montana ocorre até, aproximadamente $950 \mathrm{~m}$ de altitude, na base de morro no início do planalto (Figura 2). O segmento observado desta floresta encontra-se na fase intermediária da sucessão secundária, contrariando o que foi indicado no mapa de SEMA (2002). Verificase a existência de dossel e sub-bosque, com lianas 
com pequenos diâmetros e poucas epífitas presentes e não é observada a espécie clímax desta floresta, o pinheiro-do-paraná (Araucaria angustifolia). O dossel apresenta árvores com diâmetros pequenos, dificilmente ultrapassando os $50 \mathrm{~cm}$, não havendo, portanto, amplitude diamétrica, ou seja, as árvores possuem diâmetros com valores parecidos e a altura das árvores do dossel é de aproximadamente $12 \mathrm{~m}$. Estas características, de acordo com SEMA (1998), definem a secessão secundária intermediária, a qual deve apresentar, dentre outras características, dois estratos arbóreos, árvores do dossel com altura entre 8 e $17 \mathrm{~m}$, diâmetros entre aproximadamente 10 e $40 \mathrm{~cm}$ e pouca presença de epífitas.

$\mathrm{Na}$ área de Floresta Ombrófila Mista Montana o solo predominante (Tabelas 1 a 4 - perfil 6) foi classificado como Cambissolo Háplico Ta Distrófico lítico, o qual apresenta os horizontes $\mathrm{A}, \mathrm{B}$ e C com 10, 10 e $20 \mathrm{~cm}$ de espessura e 27, 22 e 12 $\mathbf{g ~ k g}^{1}$ de carbono orgânico, respectivamente.

Este solo está localizado no planalto e recebe pouca influencia do ambiente altomontano, o que favorece o maior acúmulo de argila e, portanto, maior retenção de água (ROSSI, 2005) e a maior decomposição de matéria orgânica, conferindo o menor teor de carbono orgânico em relação aos outros solos encontrados na área de estudo (Tabela 1). Possivelmente o elevado teor de argila determina a ocorrência da Floresta Ombrófila Mista Montana sobre o Cambissolo Háplico Ta Distrófico lítico (perfil $6)$.

Ao analisar trabalhos realizados em outras regiões montanhosas nota-se que o material geológico é muito diferenciado. No estado do Paraná, na Serra do Mar - Vila Miringuava observase a presença de riólitos e migmatitos (GHANI, 1996), já no pico Marumbi, observa-se a presença do granito Marumbi (ROCHA, 1999) e no morro Anhangava, o granito Anhangava (RODERJAN, 1994). Em regiões montanhosas no estado de Minas Gerais, observam-se quartzitos nos picos Ibitipoca e do Peão (DIAS et al., 2003) e na Serra da Mantiqueira, observa-se granito e gnaisse (BENITES et al. 2003a). Apesar da diferença do material de origem, também observa-se a presença de Cambissolos e Neossolos Litólicos nestes ambientes, sendo possível, então, realizar algumas comparações.

No presente trabalho os Neossolos e o Cambissolo Háplico Ta Distrófico lítico são classificados como rasos $(<50 \mathrm{~cm})$, enquanto que - Cambissolo Húmico Distrófico léptico é classificado como pouco profundo (> 50 d" $100 \mathrm{~cm}$ ), conforme EMBRAPA (1999). Essa pouca profundidade também em ambiente altomontano foi observada por BENITES et al. (2003a) e GHANI (1996). A existência de solos rasos e a exposição de rochas estão relacionadas à posição, à declividade e aos altos índices pluviométricos, que são encontrados normalmente nas regiões montanhosas (ROSSI e QUEIROZ NETO, 2001).

Além de serem solos rasos apresentam elevada acidez, com variação no $\mathrm{pH}$ em $\mathrm{CaCl}_{2}$ de
3,4 a 4,2 (Tabela 1). Valores de $\mathrm{pH}$ semelhantes foram observados por outros autores, como RODERJAN (1994), ROCHA (1999), BENITES et al. (2003a) e BENITES et al. (2005), o que os define como solos extremamente ácidos (EMBRAPA, 2006).

A elevada acidez é compatível com os altos índices de saturação por alumínio, que variam de 19 a $90 \%$ (Tabela 2), sendo que os maiores valores ocorrem nas maiores altitudes. DIAS et al. (2003) também encontraram variação semelhante, já GHANI (1996), RODERJAN (1994) e ROCHA (1999) encontraram sempre valores elevados acima de $70 \%$ chegando a $90 \%$.

Aliado a elevada acidez e saturação de alumínio, observa-se baixa saturação por bases, menor de $38 \%$, com variação de 3 a $38 \%$ (Tabela 2 ). De acordo com EMBRAPA (2006) saturação por bases menores que $50 \%$ caracterizam solos distróficos. GHANI (1996), RODERJAN (1994), DIAS et al. (2003) e ROCHA (1999), também observaram baixa saturação por bases, porém não ultrapassando $8 \%$.

Com relação aos teores de carbono orgânico nos horizontes superficiais dos solos estudados observa-se uma variação de 27 a $150 \mathrm{~g}$ $\mathrm{kg}^{-1}$ (Tabela 1), sendo que os maiores valores ocorrem nos solos localizados nas maiores altitudes. Este mesmo comportamento foi observado por BENITES et al. (2003) e GHANI (1996), porém RODERJAN (1994) observou o inverso, a maior quantidade de matéria orgânica ocorreu nas menores altitudes, enquanto DIAS et al. (2003) não observaram relação entre a quantidade de matéria orgânica e altitude.

Apesar dos solos encontrados na área serem rasos, com baixa fertilidade e ácidos, notase que a diferença no teor de argila e de disponibilidade de nutrientes entre estes é suficiente para a mudança do tipo da vegetação e de sua fisionomia, como citam ROSSI et al. (2005).

\section{CONCLUSÕES}

$\mathrm{Na}$ área de estudo ocorrem três formações fitogeográficas distintas, sendo duas arbóreas (Floresta Ombrófila Mista e Floresta Ombrófila Densa) e uma herbácea (Refúgio Vegetacional).

A fisionomia da Floresta Ombrófila Densa sofre alteração com o aumento da altitude, havendo redução da altura e do diâmetro das árvores e do número de estratos arbóreos. Ocorre também uma alteração no tipo predominante de epífitas que cobrem as árvores.

Foram identificadas cinco classes de solos, o Neossolo Litólico Hístico típico, Neossolo Litólico Distrófico típico, Neossolo Litólico Húmico típico, Cambissolo Húmico Distrófico léptico, e Cambissolo Háplico Ta Distrófico lítico. As classes de solos estão correlacionadas com a posição na paisagem e, de maneira geral, são rasos, ácidos, com baixa fertilidade e alto teor de matéria orgânica.

Observa-se uma alta relação entre os solos e a vegetação, sendo que, de maneira geral, os solos mais profundos, com maior teor de argila e disponibilidade de nutrientes, apresentam vegetação de maior o porte e mais complexa. 


\section{REFERÊNCIAS}

1. BENITES, V. de M.; CAIAFA, A.N.; MENDONÇA, E. de S.; KER, J.C. Solos e vegetação nos complexos rupestres de altitude da Mantiqueira e do Espinhaço. Revista Brasileira de Ciência do Solo, v. 25, n. 2, p. 661-674, 2001.

2. BENITES, V. de M.; SCHAEFER, C.E.G.R.; MENDONÇA, E. de S.; MARTIN NETO, L. Caracterização da matéria orgânica e micromorfológica de solos sob campos de altitude no Parque Estadual da Serra do Brigadeiro (MG). Floresta e Ambiente, v. 10, n. 1, p 76-85, 2003a.

3. BENITES, V.M.; CUNHA, T.J.F.; FERRAZ, R.P.D.; CAIAFA, A.N.; SIMAS, F.N.; MENDONÇA, E.S. Caracterização dos solos em duas toposseqüências sobre diferentes litologias em áreas altimontanas na Serra da Mantiqueira. Rio de Janeiro: Embrapa Solos, 2003b. (Embrapa Solos. Documentos, 57).

4. BENITES, V. de M.; MENDONÇA, E. de S.; SCHAEFER, C.E.G.R. Properties of black soil humic acids from high altitude rocky complexes in Brazil. Geoderma, v. 127, p 104-113, 2005.

5. BIGARELLA, J.J. A Serra do Mar e a porção oriental do Estado do Paraná. Curitiba: Secretaria Estadual de Planejamento/Associação de Defesa e Educação Ambiental, 1978. 248 p.

6. CORDANI, V.G.; GIRARDI, V.A.V. Geologia da folha de Morretes. Boletim da Universidade Federal do Paraná. Geologia, n. 26, p. 1-40, 1967.

7. DIAS H.C.T.; SCHAEFER, C.E.G.R.; FERNANDES FILHO, E. I.; OLIVEIRA, A.P.; MICHEL, R. F. M.; LEMOS JUNIOR, R.J.B. Caracterização de solos altimontanos em dois transectos no parque estadual do lbitipoca (MG). Revista Brasileira de Ciência do Solo, v. 27, n. 3, p 469-491, 2003.

8. EMBRAPA. Empresa Brasileira de Pesquisa Agropecuária. Centro Nacional de Pesquisa de Solos. Manual de métodos de análise de solo. 2 ed. Rio de Janeiro, 1997. $212 \mathrm{p}$.

9. EMBRAPA. Empresa Brasileira de Pesquisa Agropecuária. Centro Nacional de Pesquisa de Solos. Sistema brasileiro de classificação de solos. 2 ed. Rio de Janeiro, 2006. 306 p.

10. GHANI, N.L.B. Caracterização morfológica, física, química, mineralógica, gênese e classificação de solos altimontanos derivados de riólito e migmatito da Serra do Mar - PR. Curitiba, 1996. 197 f. Dissertação (Mestrado em Agronomia) - Setor de Ciências Agrárias, Universidade Federal do Paraná.

11. IAPAR - INSTITUTO AGRONÔMICO DO PARANÁ. Cartas climáticas do estado do Paraná, 1994. Londrina, 1994. $49 \mathrm{p}$.

12. IBGE. Instituto Brasileiro de Geografia e Estatística. Diretoria de Geociências, Departamento de Recursos Naturais e Estudos Ambientais. Manual técnico da vegetação brasileira. Rio de Janeiro, 1992. $92 \mathrm{p}$.

13. MARQUES, R.; MOTTA, A.C.V. Análise química do solo para fins de fertilidade. In LIMA, M.R. (Org.) Manual de diagnóstico da fertilidade e manejo dos solos agrícolas. Curitiba: Universidade Federal do Paraná, Departamento de Solos e Engenharia Agrícola, 2003. p. 81-102.

14. PORTES, M.C.G.O.; GALVÃO, F.A Floresta altomontana do sul do Brasil: considerações climáticas, pedológicas e vegetacionais. Cadernos da Biodiversidade, v. 3, n. 1, p. 44-50, 2002.

15. ROCHA, M.R.L. Caracterização fitossociológica e pedológica de uma floresta ombrófila densa altomontana do parque estadual do Marumbi - Morretes, PR. Curitiba, 1999. 81 f. Dissertação (Mestrado em Engenharia Florestal) - Setor de Ciências Agrárias, Universidade Federal do Paraná.

16. ROSSI, M.; QUEIROZ NETO, J.P. de. Relações solo/paisagem em regiões tropicais úmidas: o exemplo da Serra do Mar em São Paulo, Brasil. Revista do Departamento de Geografia, v. 14, p. 11-23, 2001.

17. ROSSI, M.; MATTOS I.F. de A.; COELHO, R.M.; MENK, J.R.F.; ROCHA F.T.; PFEIFER, R.M.; DeMARIA I.C. Relação solos/ vegetação em área natural no Parque Estadual de Porto Ferreira, São Paulo. Revista Instituto Florestal, v. 17, n. 1, p. 45-61, 2005

18. RODERJAN, C.V. O gradiente floresta ombrófila densa altomontana do morro do Anhangava, Quatro Barras, PR - Aspectos climáticos, pedológicos e fitossociológicos. Curitiba, 1994. 119 f. Tese (Doutorado em Engenharia Florestal) - Setor de Ciências Agrárias, Universidade Federal do Paraná.

19. SANTOS, R.D.; LEMOS, R.C.; SANTOS, H.G.; KER, J.C.; ANJOS, L.H.C. Manual de descrição e coleta de solo no campo. 5. ed. Viçosa: SBCS, 2005. 92 p.

20. SEMA - Secretaria de Estado do Meio Ambiente e Recursos Hídricos. Resolução SEMA no. 031 de 24 de agosto de 1998, que dispõe sobre o licenciamento ambiental, autorização ambiental, autorização florestal e anuência prévia para desmembramento e parcelamento de gleba rural. Curitiba: Secretaria de Estado do Meio Ambiente e Recursos Hídricos, 1998.

21. SEMA - Secretaria de Estado do Meio Ambiente e Recursos Hídricos. Mapeamento da floresta atlântica do Estado do Paraná. Curitiba: Secretaria de Estado do Meio Ambiente e Recursos Hídricos, 2002. 2 CD-ROM.

22. SIMAS, F.N.B; SCHAEFER, C.E.G.R.; FERNANDES FILHO, E.I.; CHAGAS, A.C.; BRANDÃO, P.C. Chemistry, mineralogy and micropedology on highland soils on crystalline rocks of Serra da Mantiqueira, southeastern Brazil. Geoderma, v. 125, p 187-201, 2005.

23. VASHCHENKO, Y.; FAVARETTO, N.; BIONDI, D. Fragilidade ambiental dos picos Camacuã, Camapuã e Tucum, Campina Grande do Sul, PR. Floresta, v. 37, n. 2, p. 201-215, 2007.

24. VOLKOFF, B.; CERRI, C.C.; MELFI, A.J. Húmus e mineralogia de horizontes superficiais de três solos de campo de altitude dos estados de Minas Gerais, Paraná e Santa Catarina. Revista Brasileira de Ciência do Solo, v. 8, n. 3, p. 277-283, 1984

Recebido em 06/06/2007

Aceito em 11/10/2007 
